\title{
CAMBRIDGE
}

\section{NEW AND NOTEWORTHY}

African History through Sources

Volume 1: Colonial Contexts and Everyday Experiences, c. 1850-1946

Nancy J. Jacobs

\$85.00: HB: 978-1-107-03089-3: $300 \mathrm{pp}$.

\$27.99: PB: 978-1-107-67925-2

\section{Islam, Youth,} and Modernity in the Gambia The Tablighi Jama'at

Marloes Janson

The International African Library \$99.00: HB: 978-1-107-04057-1: 320 pp.

Slave Emancipation and Racial Attitudes in Nineteenth-Century

\section{Cross-Cultural Exchange} in the Atlantic World

Angola and Brazil during the Era of the Slave Trade

Roquinaldo Ferreira

\$99.00: HB: 978-0-521-86330-8: 282 pp.

Guns, Race, and Power in Colonial South Africa

William Kelleher Storey

\$30.99: PB: 978-1-107-40396-3: 398 pp.

Witchcraft and Colonial Rule in Kenya, 1900-1955

Katherine Luongo

\$103.00: HB: 978-1-107-01218-9: 116 pp.

\section{AIDS Drugs For All}

Social Movements and Market Transformations

Ethan B. Kapstein and

Joshua W. Busby

\$95.00: HB: 978-1-107-03614-7: 337 pp.

\$34.99: PB: 978-1-107-63264-6

\section{South Africa}

R. L. Watson

\$103.00: HB: 978-1-107-02200-3: 334 pp.

\section{Slavery and Slaving in} African History

\section{Sean Stilwell}

New Approaches to African History \$90.00: HB: 978-1-107-00134-3: 232 pp. \$27.99: PB: 978-0-521-17188-5

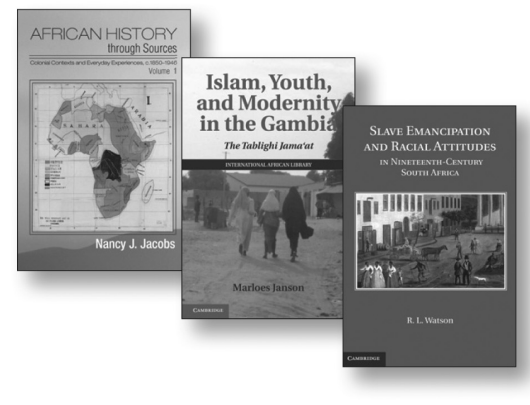

Prices subject to change.

www.cambridge.org @cambUP_History 


\section{THE JOURNAL OF MODERN AFRIGAN STUDIES \\ INSTRUCTIONS FOR CONTRIBUTORS}

Detailed instructions on how to submit your manuscript if it is accepted for publication can be found at: www.journals.cambridge.org/moa

\section{Editorial Statement}

The Fournal of Modern African Studies offers a quarterly survey of developments in modern African politics and society. It seeks to publish original empirical research, which helps to illuminate broader issues affecting Africa. Papers derived from fieldwork in Africa are particularly welcome. Its main emphasis is on current issues in African politics, economies, societies, and international relations, seeking to benefit from the work of specialists in different academic disciplines, and of those who are currently engaged in the affairs of the continent. It does not normally publish general overviews, literature surveys, or expressions of personal opinion. While recognising that sound research is an essential prerequisite for public policy, its central concern is with understanding, rather than with policy implications. Historical studies will normally be accepted only when they are directly relevant to the understanding of modern Africa.

The fournal, which is fully refereed, seeks to promote a deeper understanding of what is happening in Africa today. It is intended not only for students and academic specialists, but also for general readers and practitioners with a concern for modern Africa, living and working both inside and outside the continent. Contributions should therefore be presented in such a way as to be accessible to any informed and interested reader, and papers which take a narrowly technical or disciplinary approach will not be accepted.

Editorial policy avoids commitment to any political viewpoint or ideology, recognising that a wide range of different approaches are needed in order to understand developments in Africa, and that approaches which are unfashionable at one moment may well become widely accepted at another. Controversial papers, and papers which seek to challenge current orthodoxies, are therefore welcome, subject only to the recognition that the purpose of the foumal is to promote understanding, rather than to act as the mouthpiece for polemic.

Contributions are invited from all over the world, and those from scholars and practitioners working in Africa are particularly welcome. Articles should not be longer than 10,000 words, including references and notes. Articles submitted to the fournal should be original contributions and not under consideration for any other publication at the same time. Exceptions to this rule should be clearly indicated at the time of submission. Following publication, authors are entitled to republish their articles elsewhere, in original or amended form, provided that prior publication in The Journal of Modern African Studies is acknowledged.

All correspondence and contributions should be addressed to the Editors.

Submission of an article is taken to imply that it has not previously been published, and has not been submitted for publication elsewhere. If an author is publishing a related article elsewhere, this fact should be stated. Authors of articles published in the journal assign copyright to Cambridge University Press (with certain rights reserved) and will receive a copyright assignment form for signature on acceptance of their paper.

Contributors are responsible for obtaining permission to reproduce any material in which they do not own copyright, to be used in both print and electronic media, and for ensuring that the appropriate acknowledgements are included in their manuscript.

Correspondence by email is greatly preferred, and manuscripts should if possible be submitted in an electronic form (preferably as an email attachment in any format readable on Word-95 - not in Microsoft Vista), directly to the editor.

Unsolicited book reviews are not accepted. Book reviews and occasional review articles are commissioned by the Book Review Editor.

This journal issue has been printed on FSC-certified paper and cover board. FSC is an independent, nongovernmental, not-for-profit organization established to promote the responsible management of the world's forests. Please see www.fsc.org for information.

(C) Cambridge University Press 2014

\section{CAMBRIDGE UNIVERSITY PRESS}

The Edinburgh Building, Shaftesbury Road, Cambridge CB2 8RU

32 Avenue of the Americas, New York, NY Ioor3-2473, USA

477 Williamstown Road, Port Melbourne, vic 3207, Australia

Ruiz de Alarcón I3, 28014 Madrid, Spain

Dock House, The Waterfront, Cape Town 8oor, South Africa

Printed in the United Kingdom by Bell \& Bain Ltd. 


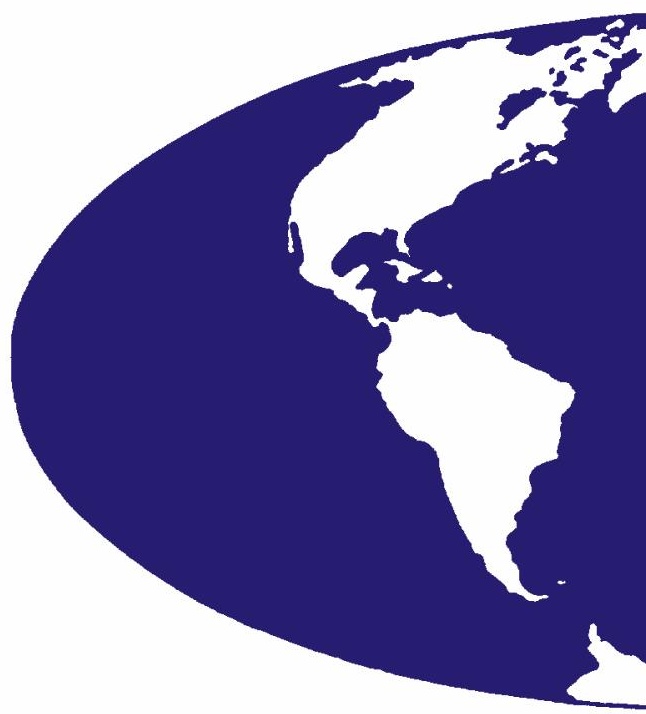

Cambridge Journals Online

For further information about this journal please go to the journal website at: journals.cambridge.org/moa $\sqrt{3}$

FSC

www.fsc.org
MIX

Paper from responsible sources FSC $^{\oplus}$ C007785
CAMBRIDGE UNIVERSITY PRESS 